\title{
BUILT HERITAGE OF THE DISMANTLED RAILWAY NETWORK: MAIN CAUSES OF ITS PERSISTENCE
}

\author{
URTZI LLANO-CASTRESANA $^{1} \&$ ANDER DE LA FUENTE ARANA ${ }^{2}$ \\ ${ }^{1}$ Faculty of Engineering in Bilbao, University of the Basque Country UPV/EHU, Spain \\ ${ }^{2}$ Department of Architecture, University of the Basque Country UPV/EHU, Spain
}

\begin{abstract}
The gradual deterioration experienced by the railway in the mid-20th century precipitated the dismantling of a great part of the once dense rail network, which articulated Europe and many of the most industrialized countries in the world, leaving a large set of infrastructures and buildings in disuse. In just a few decades since the closure of these lines, the existing number of buildings that formed these infrastructures has been decreasing alarmingly. From an academic point of view, most of the papers deal with the reasons for the continuous disappearance and destruction of railway heritage. The object of this article is to expose the main factors that have favoured the conservation of the buildings of those lines that have fallen into disuse, approaching from another perspective the vision of a reality in which both social and cultural aspects will play a role as relevant as architectural, technical and constructive ones. These lead us to the following question: Why are they still standing? To answer this question, more than 231 buildings from six disused railway lines which share similar characteristics, are close to each other and were part of one of the densest railway networks in Europe, such as the one in the Basque Country, have been analysed. Among them, the railway line of the Urola will stand out, due to its general state of preservation, experimented in the number, quality and conservation of its built elements. In this paper, we will present the different evidences why this line, coeval and analogous to the others and whose original buildings have remained almost the same, presents so different results from the rest. We will also determine and quantify the different indicators that could be relevant to define the possible level of recovery of the railway heritage in case of a hypothetical, future intervention, that could be extrapolated to the rest of the cases.
\end{abstract}

Keywords: dismantled railway network, former railway buildings, heritage management, collective identity.

\section{INTRODUCTION}

The value of the inherent historical, artistic and cultural heritage of the railways is not enough to ensure the survival of these elements and infrastructures [1], [2]. This article is framed in the context of a research that aims to develop a methodology that makes possible to "quantify" the potential or the real possibilities that disused lines have of being reused. That is, of being activated to serve society again [3]. In a comparison that showed the evolution of the state of conservation of the built heritage in closed railway lines of the Basque country, which are, among other things, close and similar to each other, it showed the relatively good state of general conservation that one of them presented with respect to the rest.

All of them were lines with regular passenger service and served an orographically complicated territory in mainly urbanized multi-centered urban regions [4]. These were built at the end of the 19th century and the beginning of the 20th century, of metric width, of regional character "valley railways" and of less than $150 \mathrm{~km}$ in length, being the average length less than $60 \mathrm{~km} / \mathrm{line}$, with at least 30 years out of service. It is worth noting the great proximity between them, converging all of them in a radius of less than $25 \mathrm{~km}$, which guarantees couples or similar situations in different areas (economic, social, cultural, orographic, climatic and environmental...).

In the following comparison, 231 initial buildings are presented, classified according to three state of preservation: 
1. State 1: Disappeared.

2. State 2: In danger. Damaged; extensively damaged; in decay; collapsing.

3. State 3: Out of danger. In an acceptable state; refurbished or not.

Table 1: Data extracted from the comparison of the state of conservation of the built heritage in former railway lines. (Source: Llano, 2014.)

\begin{tabular}{|c|c|c|c|c|c|c|}
\hline $\begin{array}{c}\text { Railway } \\
\text { line }\end{array}$ & $\begin{array}{c}\text { Length } \\
\mathbf{k m}\end{array}$ & $\begin{array}{c}\text { Years } \\
\text { closed }\end{array}$ & $\begin{array}{c}\text { No. original } \\
\text { buildings }\end{array}$ & State 1 & State 2 & State 3 \\
\hline A & 143 & 52 & $\mathbf{8 6}$ & 46 & 15 & $\mathbf{2 5}$ \\
\hline B & 22.7 & 44 & $\mathbf{1 8}$ & 16 & 1 & $\mathbf{1}$ \\
\hline C & 36.6 & 33 & $\mathbf{4 6}$ & 13 & 6 & $\mathbf{2 7}$ \\
\hline D & 11.7 & 59 & $\mathbf{8}$ & 8 & 0 & $\mathbf{0}$ \\
\hline E & 84.15 & 59 & $\mathbf{3 2}$ & 22 & 3 & $\mathbf{7}$ \\
\hline F & 51.5 & 63 & $\mathbf{4 1}$ & 37 & 1 & $\mathbf{3}$ \\
\hline Total & & - & $\mathbf{2 3 1}$ & $\mathbf{1 4 2}$ & $\mathbf{2 6}$ & $\mathbf{6 3}$ \\
\hline
\end{tabular}

It should be noted that the $\mathrm{C}$ rail still retains more than $70 \%$ of its buildings, compared to an average of $61.5 \%$ of disappeared buildings per line. In other words, the average of buildings preserved per line is reduced to a scarce $38,5 \%$. In addition, the $\mathrm{C}$ rail retains in its entirety the main buildings of the infrastructure, its 13 stations, as well as its 29 tunnels and 20 bridges, most of them in a good state of conservation. The $\mathrm{C}$ line, therefore, not only has the highest percentage of the best-preserved buildings, but it is also the line that has maintained in the best state the most relevant elements of the whole that form the infrastructure in its entirety: the Urola railway [5].

Due to this difference relevant to the rest of the cases analyzed, not justifiable only because it is the line that has spent less time in disuse, this work raises the causes that may underlie this reality and may affect the assessment process of the potential that disused railway lines can hold as a whole [6, pp. 66-67], in order to face a possible reuse of them.

\section{METHODOLOGY OR HOW TO PROCEED}

What factors have been able to intervene in this line so that most of the buildings that make it up, including all of its stations, still remain standing? The answer must also be sought in areas that may go beyond the technical-constructive factors, widely studied by other works [7, pp. 18-20], [8].

Hereunder, it is detailed the procedure that has been followed when analyzing the degree of incidence that can have a factor that is not often incorporated in the description of the process of deterioration of a building, beyond the presumed deterioration due to lack of maintenance and abandonment of the element: the human factor. This should be addressed through an analysis that includes the entire line, that is to say, it should take into account the set of architectural elements that form this linear infrastructure throughout the territory, and that generally, are grouped around a main building or station.

\subsection{Different aspects that affect the deterioration/disappearance of a station}

What causes the decay of the buildings within a railway without use? What enables or disables their conservation? In the following lines we will analyse the main causes that can bring about the decay of a building, as well as the stages of this process. 


\subsubsection{Technical-constructive aspects}

This area includes those derived from the used constructive system, materials, design, execution, and the response or behaviour and suitability that they offer against the deterioration that may occur over time, the continuous use or disuse, climatic agents, adequacy to the terrain etc. where two types of factors that can influence the deterioration of the element will be highlighted: internal/external. The former refer to factors of deterioration that only depend on the suitability of the construction itself to face the benefits and services that are presupposed, as well as adaptation to their environment. This section will analyze the main pathologies that have the greatest impact or threat to the survival of the building, with the aim of identifying possible differences that may exist between the Urola line and the rest of the biomass lines analyzed. On the other hand, external factors are those factors that affect the deterioration of the element as pathology, not attributable to the building itself, as are the progressive deteriorations caused by the human factor, which will focus on the following section.

\subsubsection{The incidence of the human factor and socio-cultural aspects}

The structure, materials, typology and arrangement/composition of a building can be the most important aspects of its functional lifespan, but there are many other variables that can have a bigger influence than the previous technical and structural factors. Among those factors we can find the levels of social awareness and closeness between the society and heritage [9, p. 3].

This section seeks to assess the degree of incidence of the human factor or society in both the deterioration and the conservation of these elements [10] by trying to know the level of identification of the inhabitants of the territory with the heritage element in question, the former railway line and its buildings.

On the one hand, within the phases of constructive deterioration that a building presents since it falls into disuse, it has also been analyzed the degree of incidence that the human factor plays as mitigating in the deterioration of the building and that are common to all the lines studied, through the following classification and criteria [9, pp. 12-13]:

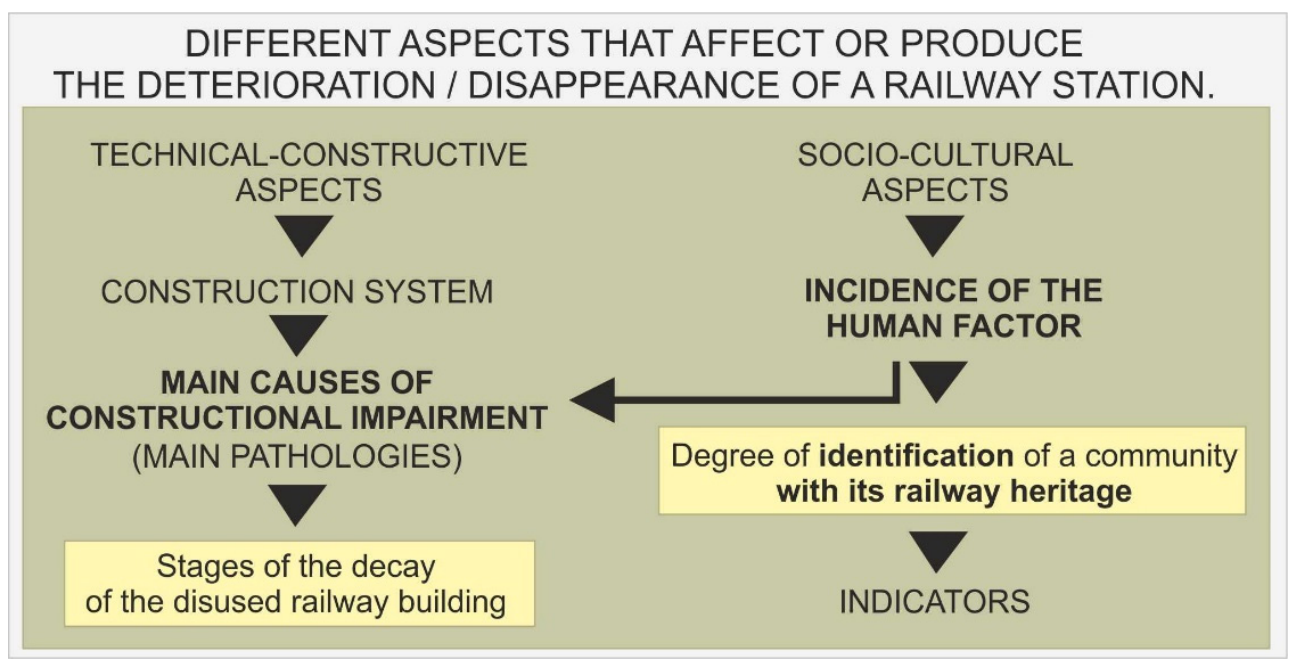

Figure 1: Scheme of applied methodology. 
The human factor in the constructive deterioration of the buildings: Just as has happened with the extensive industrial heritage that has been left without use, if not in a more meaningful way, the architectural railway heritage consists of a group of elements that have suffered the continuous impact of human actions. On the one hand, because the particular characteristics of the built elements make them easily accessible, because they comprise an unprotected or weak group elements scattered across the region, or because as towns and cities grow, the stations tend to be located close to densely populated areas with high strategic interest, within the reach of the effects of human actions. With the aim of studying the influence of humans in the decay of these buildings, this phenomenon appears soon after the building is left without use, and, at least in the case of the stations analysed, it can be summarized in the following 4 phases/stages:

1. First stage/phase: the first signs of damage appear on the external side of the building without use, such as graffiti on the facade, as well as damage on glass panes/windows and frames.

2. Second stage/phase: the first seepage takes place in the building, and in consequence, the first damage occurs, especially on furniture and goods. The plunder of elements that can have some value takes place, as well as the destruction of the rest of the objects that might remain there. Broadly speaking, this is the first damage that can cause the reduction of the lifespan of the building. This stage, that is, the first seepage gives place to a constant and faster decay of the building, unless the continuous seepage is stopped.

3. Third stage/phase: continuous seepage will happen on a sporadic/ intermittent/regular basis and the internal structure will suffer initial damage. The duration of the seepage can be longer, and the damage caused by it will be more severe. The damage suffered in this stage can be caused by a wide range of sources, such as attempts of arson, or the theft of structural elements and building services components in order to reuse them. The collapse of the building has already started and when this damage affects the state of the roof that protects the building from rainwater, this will be left without protection against damage by external natural causes.

4. Fourth stage/phase: As it has been mentioned in the previous section, when the roof of a building is damaged and the seepage of rainwater begins, the constant deterioration of the internal structure and floor slabs takes place, and along this, the worsening of the decay process of the building, the disappearance of usefulness conditions, a lack of security. Finally, as the perimeter bearing walls are strong, the roof will end up collapsing into the interior of the building.

On the other hand, it is intended to relate the degree of impact that can have on the conservation of these buildings, the level of identification that a certain community presents with respect to that built heritage, taking into account the following four indicators:

- The general state of conservation presented by the set of elements that form the heritage, in this case, the railway heritage, of that specific territory.

- The diverse cultural expressions around the railway heritage in question.

- The number of citations and references in publications, press, digital media, etc., in which the railway heritage in question is mentioned, since it fell into disuse.

- The collection of direct opinion through field study: surveys and questionnaires. 
From an objective point of view, it is difficult to quantify or measure something as complex as the degree of identification of a community with its railway heritage. The abovementioned indicators will try to approach this reality from different perspectives. The first three indicators are presented as evidence that can bring us closer to a reality that will end up being reflected through a survey or direct consultation with the population served by the railroad. For this, we have proceeded to the development of a simple questionnaire directed, on the one hand, to the generations born in the territory in which the railroad served, but they have not known it in operation, that is to say, under 33 years (spectrum 15-33), and on the other hand, those generations that have known the railroad in service, that is, the population sector with age over 33 years. The questionnaire includes five questions with which it has been tried to achieve among others, the following objectives:

Degree of awareness and identification of citizens for their railway heritage.

Degree of involvement or commitment to their railway assets.

Degree of transfer of values and generational memory of those who knew the railway service in progress towards those who have known it only in disuse.

The five questions with a double answer system, yes/no and agreement level from 1 to 5, have been formulated in the following way:

1. Do you believe that the Urola railway, while it was operational, helped to the development of the Urola region? (YES/NO). In what level? (1-5).

2. Do you believe that the Urola railway is part of the historical memory of the region? (YES/NO). In what level? (1-5).

3. Do you believe that the Urola railway is part of the identity and character of the region? (YES/NO). In what level? (1-5).

4. Do you think it would be good to develop strategies aimed at reactivating the railway heritage of the region? (YES/NO). In what level? (1-5).

Would you be willing to (be part of/integrate into) a process in which a plan for the reactivation of this heritage-infrastructure will be agreed and promoted? (YES/NO). In what level? (1-5).

\section{RESULTS: NOT ONLY THE CONSTRUCTIVE SYSTEM}

The application of the guidelines previously described in the case of line C, the Urola railway, offers the following results.

3.1 Distinctive characteristics of the construction system: reinforced concrete, instead of wood

After carrying out the analyzes related to the technical-constructive aspects, we can conclude that in technical and architectural terms, this type of buildings, medium and small typologies of railway stations, are built well and strong, though their weakest point is the roof. Since water is the natural factor that can have the most harmful effect on the building, it is essential for the building's survival that the external layers that offer protection against water are able to continue performing their function.

The effects of any structural (pathology) are greater on the roof than on any other structural elements of the building, especially since they can lead to occasional seepage which may turn into continuous one as time passes by. In fact, the damages resulting from not repairing them will have a direct impact on the internal wooden structure of most of the railway stations built at the end of the 19th century and the beginning of the 20th century. 
Even though the external bearing walls of this type of building are capable of supporting the load of the roof adequately, the internal wooden structure, damaged by the continuous rain seepage, fails to do so.

Consequently, as the interior wooden structure is unable to withstand the strain, these buildings tend to collapse inwards. Therefore, as it has been mentioned, water will be the main and most detrimental damaging cause among the natural factors and the roof will be the weakest part of the building, making it the first one to be protected so as to ensure the preservation of the building. Therefore, the unusual [11, p. 339] construction system used by Cortazar [12] in his railway stations has become a crucial factor and, together with the construction materials linked to this system, it can play an important role in the survival of a building without use or any sort of maintenance.

One of the reasons why such a large number of buildings has survived to our days in the railway of Urola as opposed to the destruction of heritage that has happened around them and especially in the Gipuzkoan side of the rest of the railways, which have been closed for more than 30 years and have undergone no restoration process, may lie in their internal concrete structures, and above all, the fact that the roof beams and the roof itself are made of reinforced concrete. Even though the roof of many buildings suffer from rain water seepage, the behaviour of the concrete in the presence of this seepage is better than the wooden structures', in terms of ensuring the protection and support of the rest of the building. However, the continuous entrance of water into a building leads to very harmful consequences, and the destruction of the building in the short term. In the case of Urola, the concrete has postponed the decay of the building a few years, and the main reason why the substation of Vascongados in Bergara (Railway line B) has not disappeared yet could be to a great extent its reinforced concrete internal and roof structures.

\subsection{Degree of incidence of the human factor in the conservation or disappearance of the built railway heritage}

When the human factor is included in the decay process of the railway heritage, it becomes undoubtedly the activity with the greatest impact. If its influence on the disappearance of the heritage is to be studied, the continuous expansion policies of cities, which are often far from meeting the demands of the society, and the new infrastructures that will serve them have to be taken into account. In fact, the loss of many railway infrastructures and architectural elements come as a result of the excessive urban growth our country has sustained in the last decades, and the resulting pressure from the real estate business and the substantial profits stemming from it. Sometimes, this loss was unavoidable, but on most occasions this came about due to a lack of awareness, culture of reusing, and willingness. Thus, most of the buildings left without use that were located in towns and cities have disappeared progressively.

Therefore, among the factors that have brought about the decay, destruction and disappearance of the architectural railway heritage, rather than the materials and systems used for its construction, in other words, the design and suitability of the building to resist the effects of the weather, it is humans that represent the main factor that speeds up the deterioration of these buildings. According to its influence described before and according to the analysed cases, these are in general the different stages of the decay of the disused railway building:

1. Lack of use.

2. First external damage: 
2.1. Superficial damage: Graffiti/appearance of.

2.2. Deeper damage: breakage of windows/deterioration of frames.

3. Break-ins:

3.1. First break-ins, theft, material damage.

3.2. Continuous or repeated occasional short but harmful occupations, first fires, burglary, and damage to the buildings.

4. First damage to the building skin or envelope, especially the roof: first seepage.

5. Continuous deterioration of the internal structure.

6. Collapse of the roof and quick and total destruction of internal spaces.

7. Disappearance of construction elements above ground level.

Notice that in order to avoid the security issues that these situations can cause, in many cases the administration in charge of the maintenance of the building has opted for its demolition.

\subsubsection{The phenomenon of "occupation"}

The "occupation" of the building, turns out to be a rather unfortunate option for the element that has to be protected, even though there might be the occasional exception here as well. We must take into account that this situation is not a phenomenon confined to our present time, since it is a phenomenon that started a long time ago in our society. An occupation comes about to a certain extent as a result of the needs of a group of people that are also part of the society. In most cases, it takes place when there is a lack of use of a building, and there are two factors involved in this process: the neglect of the heritage by the owners and the people who take advantage of the possibilities this situation offers. There are many stations in our railways in this state of occupation, and even though the impact this situation can have on the building is generally speaking harmful, there are some exceptions in which the occupants have taken on the responsibility of maintaining the building. However, the instability of this type of situations can be a hindrance that prevents the occupants from developing a proper sense of responsibility towards the building they are occupying. According to this, we can distinguish two types of occupations: the responsible and irresponsible towards the building. Either way, this situation that railway buildings have to go through has detrimental effects on the architectural heritage, and it can be said that, generally speaking, actions that are not regulated and are carried out without a plan that can provide a certain degree of stability are far from beneficial to the heritage.

Eight of the 33 railway buildings that remain in the valley of Urola are in the aforementioned state, which account for almost a quarter of the railway heritage. To make matters worse, many other buildings, Aizpurutxo station among them, have been through this situation before and they are still under constant threat. Unfortunately, the lack of continuity of this occupation that could provide a certain level of stability to its active users which usually results in some slowdown in the process of deterioration of the building, and the negligence of the public owners, have left the building without use, condemning it to its current lamentable state.

Considering all the aforementioned, we should bear in mind that, in the end, the occupation of buildings shows a lack of ability of the authorities/public ownership to promote different proposals and projects in order to offer the usefulness this buildings can offer to society or to take advantage of their restoration, and that they are the result and reflection of the lamentable state of the built heritage. 
3.2.2 The identification level of the society with its railway heritage

On the other hand, even though it can be decisive in the disappearance of the railway heritage, the human factor also plays a crucial role in the challenge of the survival of these heritage poses, a role it will continue playing in the following years. The clearest evidence of this assertion is the survival of the buildings in the railway of Urola. Even though the buildings in the railway of Urola have been out of service for a shorter period of time than the rest of the railways, 30 years, the most decisive factor in their survival, apart from the fact of their structure being made of reinforced concrete, would be the extraordinary level of social awareness and closeness between the society and this heritage. The clearest evidence of the existence of this factor is the survival of almost the whole of this infrastructure since it had been left without use to these days, being the station of Urola in Zumarraga the most representative example. This building that is strategically located in the square of the stations and parallel to the Urola river has suffered the effects of the growth promoted by the real estate market, and different urban developments have surrounded it in the last decades, with almost no space to breathe as a result of an urban development that seems totally forced/contrived. Although the station building was a clear obstacle to these developments, the main building and the neighbouring toilets that serve the former have remained unaltered, including the railway infrastructure, thanks to the strength shown by the social movements in favour of these infrastructures that emerged from the controversial closure of the railway of Urola. In fact, this valley never refused to restart making use of this infrastructure, showing this willingness clearly in the following years and decades [13]. The refusal to give up on this willingness is one of the main reasons why these buildings still survive nowadays. As decades passed by and without any clear commitment of the Basque Government on the future of the railway, many councils of the valley fostered different initiatives in order to protect these elements on their own.

However, these initiatives were not based on a global perspective that could be more enriching and help them come closer to their goals. Thus, while the worthy station of the railway of Vascongados in Zumarraga, built at the end of the 19th century and located just a

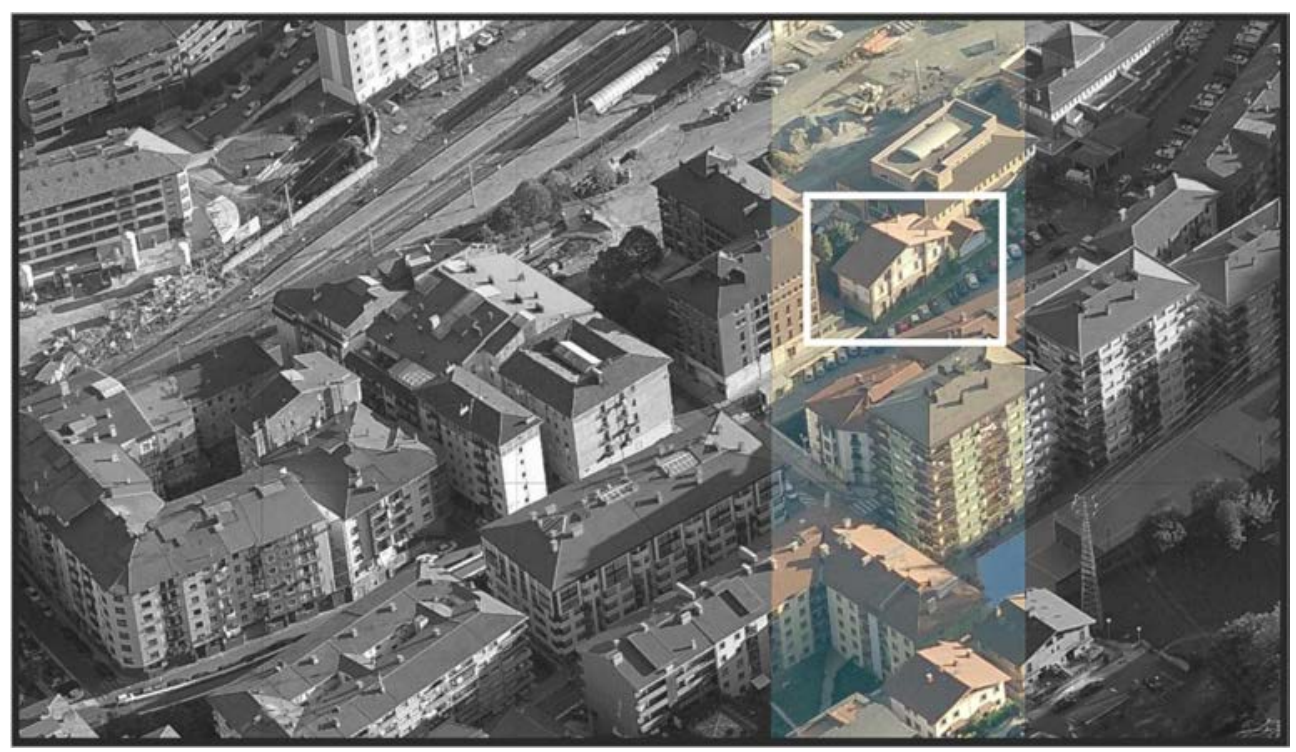

Figure 2: Current situation of the Zumarraga former railway station. 
few steps away from Urola station, was demolished at the end of the 1990s, the station of Urola would remain unaltered. Among other reasons, the demolition of this building would be seen as the first step of a process that would destroy the wish of the inhabitants to see the railway infrastructure of the valley that they were so attached to back in operation. So the building remained unaltered to a large extent, among other possible reasons, because they didn't want to be the first town of the region that would cause the admission of that reality or become responsible for the fact that this shared desire [14, p. 276] cannot be materialized any more.

This factor would have a great influence on the rest of the towns of the valley for which the railway provided service and different initiatives were developed in favour of the protection of these buildings and infrastructures.

The results obtained for the survey whose objective is to collect the degree of identification and sensitization of society to this industrial heritage are presented in Tables 2 and 3 .

Table 2: Results from the questionnaire applied to the inhabitants of the Urola region with an age between 15 and 33 .

\begin{tabular}{|c|c|c|c|c|c|}
\hline & 1st Question & 2nd Question & 3rd Question & 4th Question & 5th Question \\
\hline YES & 230 & 230 & 230 & 230 & 169 \\
\hline NO & 0 & 0 & 0 & 0 & 61 \\
\hline 1 & 0 & 2 & 6 & 2 & 3 \\
\hline 2 & 7 & 13 & 20 & 15 & 30 \\
\hline 3 & 65 & 59 & 90 & 55 & 54 \\
\hline 4 & 111 & 90 & 79 & 76 & 44 \\
\hline 5 & 47 & 66 & 35 & 82 & 38 \\
\hline
\end{tabular}

Table 3: Results from the questionnaire applied to the inhabitants of the Urola region with an age over $>33$.

\begin{tabular}{|c|c|c|c|c|c|}
\hline & 1st Question & 2nd Question & 3rd Question & 4th Question & 5th Question \\
\hline YES & 185 & 185 & 185 & 182 & 140 \\
\hline NO & 0 & 0 & 0 & 3 & 45 \\
\hline 1 & 0 & 2 & 5 & 4 & 5 \\
\hline 2 & 3 & 2 & 9 & 6 & 10 \\
\hline 3 & 30 & 14 & 34 & 33 & 36 \\
\hline 4 & 60 & 45 & 56 & 46 & 31 \\
\hline 5 & 92 & 122 & 81 & 93 & 58 \\
\hline
\end{tabular}

The results of the first three indicators analyzed, evidence a clear social implication for the defense of the railway heritage. Nevertheless, it is necessary to apply all the proposed indicators. Thus, the data that is derived directly from the results obtained in the survey indicate, among other things, the following:

- The level of awareness and identification of the inhabitants of the Urola valley with their railway heritage is very broad, both on the part of those generations that could see the railway in operation and on the part of those who could not see it. 
- The sense of identification, awareness and collective memory for this heritageinfrastructure has been transmitted to the following generations and this transmission has been made from multiple ways that exceed the family. And this transmission has also occurred in the young descendants of people who, not being autochthonous in the valley and therefore not having been users of the rail service, decided to settle in the valley.

- In response to the fourth question, a large majority of respondents believe that it would be positive to develop strategies aimed at reactivating the railway heritage of the valley.

- According to obtained data, the degree of social involvement and commitment for the promotion of projects aimed at ensuring the permanence of the railway heritage of the valley is high and this sensitivity has also been collected by its young people who did not see that train in operation [15]. Analyzing the results of the last question, perhaps the most relevant of all insofar as it appeals to the willingness to devote real time and effort, that is, it probes the potential involvement of society with its heritage in possible future laying projects in value, the results of those who have answered affirmatively to this question exceed $70 \%$ in both population segments.

These data do not come but to reaffirm the previous three indicators proposed. It would be pending to apply this questionnaire in the rest of neighboring territories with disused railroads to be able to establish a direct comparison on the obtained results. However, it should be noted that by applying the three previous indicators, a greater awareness and identification of the society of the Urola region with its railway heritage is clearly visible, which is why it has been chosen as a case study compared to the rest.

\section{CONCLUSIONS: THE KEY IS IN THE SOCIAL AWARENESS LEVEL}

Due to everything mentioned previously, referring to the initial question about the factors that may have influenced the main buildings that are part of the railroad in disuse of the Urola still stand or have not disappeared, we must highlight two.

On the one hand, the success in the chosen construction system, in which in the absence of pillars, the integral structure of the roof, the interior slabs and the interior structure of the building are executed in high quality reinforced concrete, extracted from the nearby quarries of the valley itself, replacing the traditional wooden structure and allowing the extension of the useful life of the building, as the structure is more resistant to the main pathologies that affect these buildings in disuse. However, this technical-constructive aspect is not the only reason for the non-disappearance of the majority of buildings that are part of the infrastructure in the case study. The vast majority which is located in urban or peri-urban areas is subjected to the same high speculative and immobile pressure that in any of the other analyzed lines have involved the unconditional demolition of the railway buildings.

This study highlights that, among the reasons for the decay of the architectural railway heritage, the impact of downtime of the infrastructure has been without use/out of service is as important as the systems and materials used in the construction of these elements. And even more important would be the level of social awareness and identification with these buildings of the people of the region where these were located.

This is the true relevant factor that would explain the non-disappearance and exceptional state of general maintenance of the set of buildings that make up the railway infrastructure that fell into disuse more than 30 years ago in Urola valley. If we understand this, we can reorient the policies of heritage management to emphasize their efforts to maintain and enhance the degree of identification that society has to their heritage, through awareness and 
disclosure. It is in these foundations on which future strategies of intervention and recovery of railway heritage have to be located, from a joint and integrating vision of all the possible assets that are part of the set of elements to be reactivated, we speak of a symbiosis between heritage resources and the social assets.

\section{REFERENCES}

[1] Richards, J.M., The Euston murder. Architectural Review, 131, pp. 235-238, 1962.

[2] The Times, How Euston arch will be demolished, 28 Sept. 1961.

[3] Llano Castresana, U. et al., The value of railway heritage for community development. Structural Studies Repairs and Maintenance of Heritage Architecture, vol. 131, ed. C.A. Brebbia, WIT Press: Southampton and Boston, 2013.

[4] Bertolini, L., Nodes and places: Complexities of railway station redevelopment. European Planning Studies, 4(3), pp. 331-345, 1996.

[5] Llano Catresana, U., Erabilerarik gabeko burdinbideen ondare arkitektonikoa: Lurralde baliabide aktibagarri. Egungo egoeraren azterketa. ALDIRI, 33, pp. 37-43, 2018.

[6] ICOMOS, The Burra Charter: The Australia ICOMOS Charter for Places of Cultural Significance, Australia ICOMOS Inc.: Burwood, 2013.

[7] Rodriguez, V. et al., Manual de patología de la edificación, Universidad Politécnica de Madrid: Madrid, 2004.

[8] Patología de la Construcción, Enciclopedia Broto, Gustabo Gili: España, 2004.

[9] Plan Nacional del Patrimonio Industrial, Instituto Patrimonio Cultural de España and Ministerio de Educación, Cultura y Deporte: Madrid, 2011.

[10] ICOMOS, The Dublin Principles, Joint ICOMOS-TICCIH Principles for the Conservation of Industrial Heritage Sites, Structures, Areas and Landscapes. 17th ICOMOS General Assembly on 28 Nov. 2011, Paris.

[11] Burgos Nuñez, A., Los origenes del hormigon armado en España, Ministerio de Fomento: Madrid, 2009.

[12] Azpiri, A., et al., Gipuzkoa, Guía de Arquitectura de 1850-1960. Gipuzkoako Foru Aldundia-Euskal Herriko Arkitektoen Elkargo Ofiziala, Gipuzkoa: Donostia-San Sebastián, 2004.

[13] Silva, A., Se cumplen 30 años del decreto para el cierre definitivo del Urola. www.diariovasco.com/costa-urola/azpeitia/azpeitia-perdio-tren-20180826001845ntvo.html. Accessed on: 26 Aug. 2018.

[14] Arteche Elejalde, I. et al., El ferrocarril del Urola, 1926-1986, Gobierno Vasco \& Ayuntamiento de Azpeitia, 2002.

[15] Juaristi, U., Urola in Bostekoa. https://maxixatzen.eus/azkoitia/1551177811510urolako-trena-margotu-du-udane-juaristik-zumarragara-bideko-bidegorrian. Accessed on: 26 Feb. 2019. 